Tropical Journal of Pharmaceutical Research December 2013; 12 (6): 935-939

ISSN: $1596-5996$ (print); 1596-9827 (electronic) (C) Pharmacotherapy Group, Faculty of Pharmacy, University of Benin, Benin City, 300001 Nigeria.

All rights reserved.

Available online at http://www.tjpr.org Original Research Article http://dx.doi.org/10.4314/tjpr.v12i6.11

\title{
Analgesic Effect and Immunomodulation Response on Pro-Inflammatory Cytokines Production by Scrophularia megalantha Extract
}

\author{
Abbas Azadmehr ${ }^{1}$, Mohammad Sofiabadi ${ }^{{ }^{*}}$ and Reza Hajiaghaee ${ }^{2}$ \\ ${ }^{1}$ Cellular and Molecular Research Center, Qazvin University of Medical Sciences, Qazvin, ${ }^{2}$ Department of Pharmacognosy and \\ Pharmaceutics Department of Medicinal Plants Research Center, Institute of Medicinal Plants, ACECR, Karaj, Iran.
}

*For correspondence: Email: mohasofi@yahoo.com; Tel/Fax: +982813336004

Received: 27 December 2012

Revised accepted: 24 October 2013

\begin{abstract}
Purpose: The remains unknown, To determine the analgesic and anti-inflammatory activities of Scrophularia megalantha in male rats in order to understand the scientific basis for its trado-medicinal uses, especially in inflammation.

Methods: The extract of Scrophularia megalantha was obtained with ethanol. In order to determine qualitatively the chemical components of the extract, thin layer chromatography (TLC) was used. The analgesic activity of the extract at various doses (25, 50, 100 and $200 \mathrm{mg} / \mathrm{kg}$, i.p) was assessed using formalin test while pro-inflammatory cytokines were measured by enzyme-linked immunosorbent assay (ELISA), respectively. Diclofenac (5 mg/kg) was used as positive control.

Results: Phenolic compounds, flavonoids and phenyl propanoid were present in the extract. At doses of 100 and $200 \mathrm{mg} / \mathrm{kg}$, the extract showed significant analgesic effects $(p<0.05, p<0.01)$ in the first phases of formalin test, compared with the control. At 25, 100 and $200 \mathrm{mg} / \mathrm{kg}$ doses, the extract reduced significantly $(p<0.05, p<0.001, p<0.001)$ pain score in the chronic phases of the formalin test. In addition, at $50-200 \mu \mathrm{g} / \mathrm{mL}$ of the extractm both TNF- $\alpha$ and IL-6 proinflammatory cytokines were inhibited significantly $(p<0.001)$ on LPS-stimulated macrophages.

Conclusion: The extract of S. megalantha exerts analgesic and anti-inflammatory activities by inhibition of pro-inflammatory cytokines production. This lends support for the use of the plant as an analgesic in traditional medicine.
\end{abstract}

Keywords: Scrophularia megalantha, Analgesic, Inflammation, Pro-inflammatory cytokines, Phenolics, Flavonoids

Tropical Journal of Pharmaceutical Research is indexed by Science Citation Index (SciSearch), Scopus, International Pharmaceutical Abstract, Chemical Abstracts, Embase, Index Copernicus, EBSCO, African Index Medicus, JournalSeek, Journal Citation Reports/Science Edition, Directory of Open Access Journals (DOAJ), African Journal Online, Bioline International, Open-J-Gate and Pharmacy Abstracts

\section{INTRODUCTION}

Chronic pain is the most common symptom that brings a patient to the physician. Currently available analgesic drugs such as opiates and non-steroidal anti-inflammatory drug (NSAID) are not fully accepted due to their adverse effects. For example, opioids may induce physical dependence, tolerance and other side effects including respiratory depression, drowsiness, nausea, constipation and alterations of endocrine and autonomic nervous system activities. Also NSAIDs can aggravate peptic ulcers and cause hepatorenal complications. Consequently, there is renewed interest in new natural analgesics, especially of plant origin $[1,2]$.

Inflammation plays role in the mechanism of pain. It can decrease pain threshold, increase nociceptive neuron firing rate and facilitate pain 
transmission; these processes can augment pain $[3,4]$. On the other hand, the process of inflammation is necessary for healing of damaged tissues. In response to inflammation, a variety of innate immune cells such macrophages can be activated. However, uncontrolled inflammation induces tissue injury. Cytokine production is a primary step of the reaction of macrophages to inflammatory stimuli [5]. During inflammation, the over-production of inflammatory cytokines such as TNF- $\alpha$, IL- 6 and IL-1 by activated macrophages is a crucial event for triggering progressive stimulation of immune cells [6].

One of the plants said to have immunomodulatory and anti-inflammatory effects is Scrophularia megalantha Boiss (Scrophulariaceae) $[7,8]$. Several species of this genus have been used since ancient times as folk remedies for ailments such as inflammatory diseases, scabies, eczema, psoriasis, tumors, etc. In addition, we have previously demonstrated the inhibitory effect of Scrophularia striata extract on nitric oxide production using in vitro and ex vivo models [7]. Some species in this genus have shown anti-inflammatory activity [8]. Therefore, the objective of the present study was to investigate the effect of the ethanol extract of the aerial parts of Scrophularia megalantha on proinflammatory cytokines, including TNF- $\alpha$ and IL-6 denerated by LPS-stimulated macrophages, and formalin-induced inflammatory pain in male rats.

\section{EXPERIMENTAL}

\section{Plant material and preparation of extract}

The aerial parts of Scrophularia megalantha were collected from Kelardasht Region (Mazandaran Province) in the northern part of Iran, in May 2011 and air-dried at room temperature. The plant was identified by $\mathrm{Mr}$. Ajani of the Department of Botany, Institute of Medicinal Plants (IMP) of Karaj, Iran. A voucher specimen (no. 1461) was deposited in the herbarium of the institute. The plant material was dried, powdered, and $100 \mathrm{~g}$ macerated with $80 \%$ ethanol $(900 \mathrm{ml})$ for 3 days with three changes of the solvent. The resulting extract was filtered and evaporated under vacuum to a dry powder (yield, $12.1 \%$ ). The plant extract was dissolved in dimethylsulfoxide (DMSO) to contain $0.1 \% \mathrm{w} / \mathrm{v}$ of the extract and used at appropriate concentrations.

\section{Phytochemical assay}

In order to recognize chemical components of the extract, thin layer chromatography (TLC) was used. A variety of indicators including vanillin sulfuric acid; ferric chloride and natural product polyethylene glycol were used in this assay. The indictors were sprayed on prepared thin layers of fractions and observed at 260 and $280 \mathrm{~nm}$ wavelength under UV light.

\section{Animals}

Rats $(230-250 \mathrm{~g})$ were purchased from the Pasteur Institute of Iran (Tehran, Iran). All the animal experiments were approved by and performed according to the guidelines of the Ethical Committee of Cellular and Molecular Research Center (CMRC) of Qazvin University of Medical Sciences (approval ref no. 11.3.2011CN157). The animals were maintained under standard laboratory conditions of temperature $\left(23 \pm 2{ }^{\circ} \mathrm{C}\right)$ and light/dark cycle of $12 \mathrm{~h} / 12 \mathrm{~h}$, and received standard rat chow and water ad libitum.

\section{Formalin test in rats}

Analgesic activity was performed using formalin test as described by Dubuisson and Dennis [9]. Briefly, the rats were divided into 6 groups, each consisting of seven rats. The rats were moved to the test room $1 \mathrm{~h}$ before the experiment and acclimatized for $30 \mathrm{~min}$ in an acrylic observation chamber (30 $\mathrm{cm}$ in diameter and height) prior to intraperitoneal administration of the extract $(25$, 50,100 and $200 \mathrm{mg} / \mathrm{kg}$ ) or diclofenac- $\mathrm{Na}$ (5 $\mathrm{mg} / \mathrm{kg}$ ) or normal saline $(1 \mathrm{ml})$, Thirty minutes later, $50 \mu \mathrm{L}$ of $2 \%$ formalin was injected subcutaneously into the plantar surface of the right hind paw with a 30-gauge needle. Each rat was then immediately returned to the observation chamber, and pain behavior recorded. Pain behavior was scored (at 1-min interval for 60 min) as follows: 0 , the injected paw was not favored; 1 , the injected paw had little or no weight placed on it; 2, the injected paw was elevated and not in contact with any surface; and 3 , the injected paw was licked or bit. The behavioral response of each rat during the early phase $(1-7 \mathrm{~min})$ and the late phase $(15-60$ $\min$ ) was separately evaluated [9].

\section{Isolation of peritoneal macrophages from rats}

The rats were killed by cervical dislocation and peritoneal macrophages were harvested immediately by lavaging with ice cold sterile phosphate buffer saline (PBS). The cells were washed twice and plated in RPMI 1640 medium (Sigma Chemical Co) containing $10 \%$ fetal bovine serum (Gibco), $100 \mathrm{U} / \mathrm{ml}$ penicillin and $100 \mu \mathrm{g} / \mathrm{ml}$ streptomycin (Sigma Chemical Co), and incubated for $2 \mathrm{~h}$ at $37{ }^{\circ} \mathrm{C}$ in $5 \% \mathrm{CO}_{2}$ humidified incubator. Non-adherent cells were 
removed by gently washing with PBS and freshly prepared medium was added. Cell viability was checked by trypan blue exclusion technique. An aliquot of the cell suspension was mixed with an equal volume of $0.4 \% \mathrm{w} / \mathrm{v}$ trypan blue in PBS and incubated for $10 \mathrm{~min}$. The viability of the macrophages was $>98 \%$.

\section{Measurement of pro-inflammatory cytokines}

LPS $(1 \quad \mu \mathrm{g} / \mathrm{ml}) \quad$ stimulated peritoneal macrophages were co-incubated with extract (10 - $200 \mu \mathrm{g} / \mathrm{ml}$ ) or medium alone for $24 \mathrm{~h}$. The supernatant was obtained by centrifugation at $2500 \mathrm{rpm}$ for $20 \mathrm{~min}$ and assayed for TNF- $\alpha$ and IL-6 using ELISA kits (Bio-Source, Camarillo, CA, USA) according to the manufacturer's instructions.

\section{Statistical analysis}

Data are presented as mean \pm standard deviation (SD). Statistical analyses were performed by one-way analysis of variance (ANOVA) to express difference among the groups followed by Bonferroni post hoc test. All analyses were performed using SPSS software, version 16. Differences were considered statistically significant at $p<0.05$.

\section{RESULTS}

\section{Chemical components of the extract}

Phytochemical assay by thin layer chromatography showed the presence of phenolic compounds, flavonoids and phenyl propanoids in S. megalantha extract.

\section{S. megalantha extract reduced pain symptoms}

Both acute (early) and chronic (late) phases of pain were observed in all groups after formalin injection (Fig 1).

In the acute phase, the extract decreased dosedependently pain symptoms in comparison to control that was significant at 100 and $200 \mathrm{mg} / \mathrm{kg}$ dose $(p<0.05, p<0.01)$ as shown in Fig 2A. The positive control, diclofenac-Na $(5 \mathrm{mg} / \mathrm{kg})$, significantly inhibited formalin-induced pain in the late phase $(p<0.01)$ (Fig 2B); however, there was no inhibition in the early phase (Fig $2 \mathrm{~A}$ ).

The extract significantly inhibited the late phase of formalin-induced pain, compared with control (Fig 2B). The inhibitory effect of extract (100 and $200 \mathrm{mg} / \mathrm{kg}$ ) was stronger than that of the positive control, diclofenac-Na $(5 \mathrm{mg} / \mathrm{kg})(p<0.001)$.

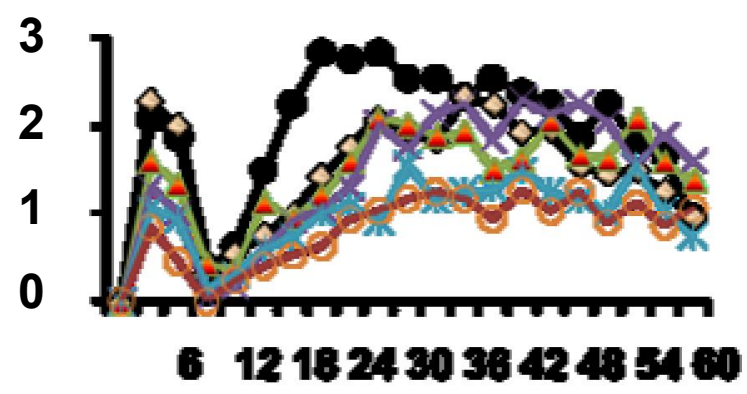

Time after formalin injection (min)

Fig 1: Effect of $S$. megalantha extract $(25,50,100$, $200 \mathrm{mg} / \mathrm{kg}$, i.p.) and diclofenac (5 mg/kg, i.p.) on $2 \%$ formalin-induced inflammatory pain in male rats. Data are presented as mean $\pm \operatorname{SD}(n=7)(\bullet=$ control; $\bullet=$ diclofenac; $\boldsymbol{\Delta}=$ Extract $25 \mathrm{mg}$ )

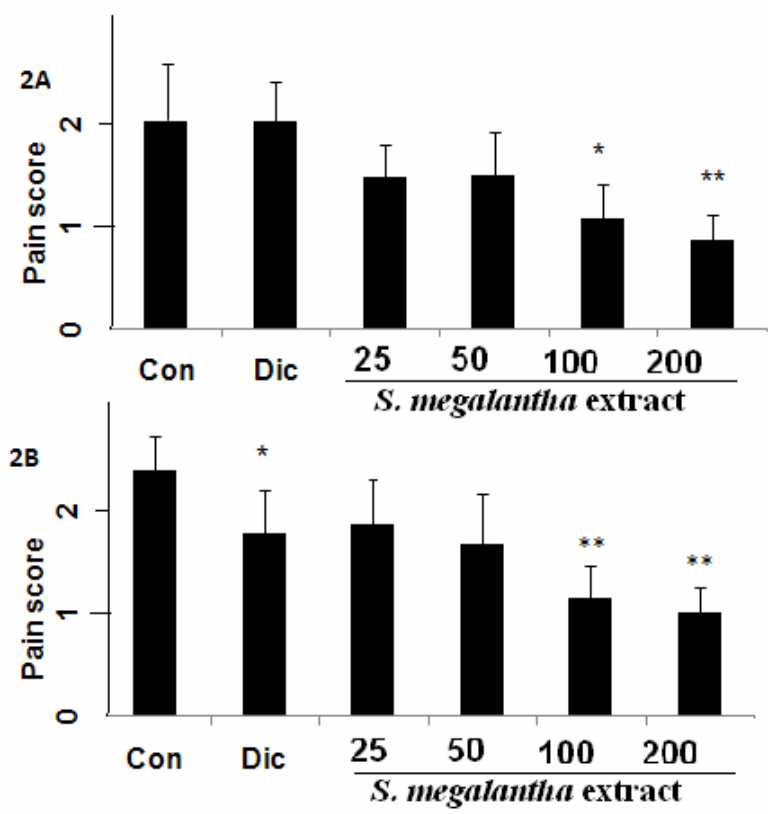

Fig 2: Effect of $S$. megalantha (25, 50, 100 and $200 \mathrm{mg} / \mathrm{kg}$, i.p.) and diclofenac (5 mg/kg, i.p.) on $2 \%$ formalin-induced inflammatory pain (early and late) phases in male rats. The extract reduced pain scores dose dependently in early phase $2 \mathrm{~A}(0-5 \mathrm{~min})$ and late phase $2 B(15-40 \mathrm{~min})$. Data are represented as mean $\pm \mathrm{SD}(\mathrm{n}=7) .{ }^{*} p<0.05,{ }^{* *} p<0.01,{ }^{* * *} p<0.001$ compared with the control group

\section{S. megalantha extract reduced LPS- stimulated proinflammatory cytokines production in peritoneal macrophages}

The effect of co-culture of LPS and extract for 24 $h$ on the release of TNF- $\alpha$ and IL-6 proinflammatory cytokines into the medium is shown in Figs 3 and 4. Rat macrophages responded strongly to the addition of LPS by releasing TNF$\alpha$ and IL-6 into the supernatant medium. Treatment of the cells with $S$. megalantha extract attenuated, in a concentration-dependent manner, the production of both pro-inflammatory cytokines by macrophages. The extract 
significantly $(p<0.001)$ inhibited the production of both cytokines by LPS-activated macrophages in the concentration range of $50-200 \mu \mathrm{g} / \mathrm{ml}$. The inhibition of TNF- $\alpha$ and IL- 6 cytokines at the concentration of $200 \mu \mathrm{g} / \mathrm{ml}$ was approximately 65 and $25 \%$ LPS only treated cells, respectively. Thus, inhibition of TNF- $\alpha$ was higher than of IL-6 after treatment of the macrophages with extract.

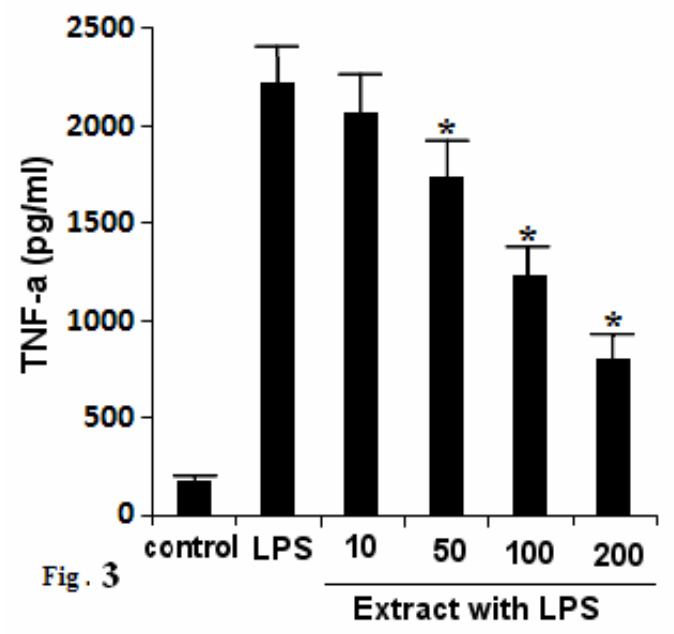

Fig 3: Effect of $S$. megalantha extract on LPSstimulated TNF- $\alpha$ pro-inflammatory cytokine production in rat peritoneal macrophages. The extract significantly $(p<0.001)$ inhibited the production of TNF- $\alpha$ cytokine by LPS activated macrophages. Data are presented as mean $\pm S D$.

\section{DISCUSSION}

S. megalantha is an important genus consisting of about 60 species in the Iran [10]. Most species belonging to Scrophularia genus have been used for anti-inflammatory therapy in folk medicine. A pervious study showed that some spices of Scrophularia have various flavonoids with antiinflammatory properties; this study also indicates that $S$. megalantha extract contains flavonoids [11].

Phenylpropanoids play multiple important biologic roles, for example, anti-inflammatory action by reducing pro-inflammatory stimuli [12]. On the other hand, several reviews have reported the anti-inflammatory activity of phenols, attributing their properties not only to antioxidant capacity, but also to pro-inflammatory mediator modulation [13]. Our results show that phenolic compounds, flavonoids and phenyl propanoids are present in S. megalantha extract. Therefore, it is probable that the extract would exert analgesic and anti- inflammatory actions.

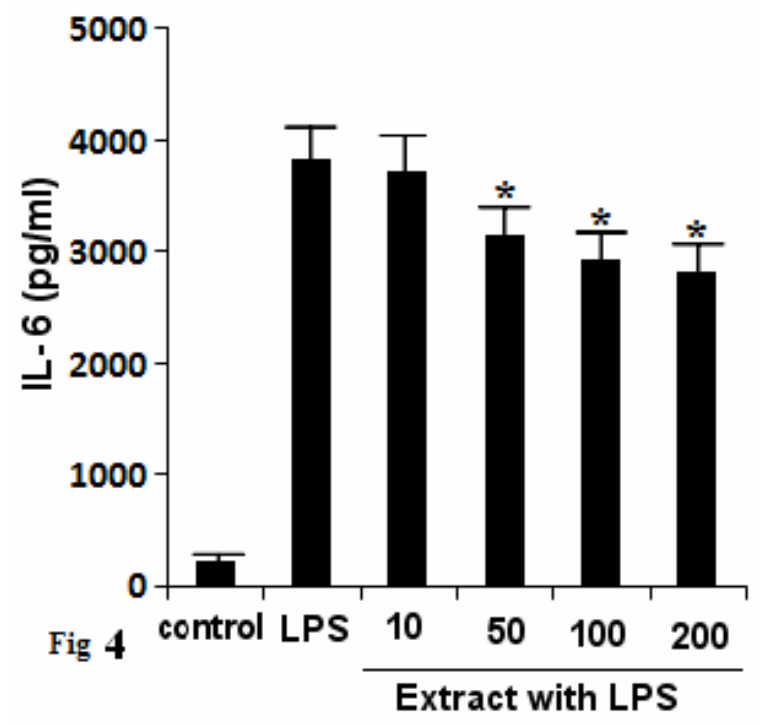

Fig 4: Effect of $S$. megalantha extract on LPSstimulated IL-6 pro-inflammatory cytokine production in rat peritoneal macrophages.

The present results indicate that the ethanol extract of S. megalantha reduced symptoms of pain dose-dependently in both acute and chronic pain phases. This suggests that the extract exerts its analgesic action by both peripheral and central mechanisms. When formalin is injected into the footpad of an animal, it produces two phases of nociceptive behavior that are separated by a short period of quiescence in which there is no apparent pain. The first or acute phase typically occurs in the first 5 min while the second starts from $15 \mathrm{~min}$ and lasts about 40 - 60 min after injection. The early phase seems to be caused mainly by direct activation of both low-threshold mechanoreceptors and nociceptive primary afferent fibers due to peripheral stimulus. The late phase, also called the tonic phase, appears to be dependent on the combination of inflammatory reaction in the peripheral tissue and functional changes at some level of the central nervous system, spatially in the dorsal horn of the spinal cord, generally called central mechanisms [14].

In the present study, we observed more intense analgesic effect on the late (inflammatory) phase in the formalin test and the results show that the extract has potent analgesic effect. Therefore, it contains compounds that act peripherally and reduce inflammation [15]. In addition, our results indicate that the anti-nociceptive effect of the extract may be due to its anti-inflammatory effect. Pro-inflammatory cytokines, such as interleukin-6 (IL-6), is a cytokine initially indentified as T-cell derived factor regulating B-cell growth and differentiation. Furthermore, deregulation of IL-6 production has been implicated in a variety of 
inflammatory diseases [16]. Pro-inflammatory cytokines such as IL-1 and tumor necrosis factor$\alpha$ (TNF- $\alpha$ ) markedly stimulate IL-6 production [17]. These mediators are able to recruit leukocytes, such as neutrophils, as reported for several experimental models $[18,19]$. In the present study, the levels of TNF- $\alpha$ and IL- 6 were significantly decreased when treated with the extract. Thus, a putative anti-inflammatory mechanism could be associated with the degree of inhibition of pro-inflammatory mediators, such as TNF- $\alpha$ and IL-6. Our results indicate that the extract exhibited antinociceptive and antiinflammatory activities. Although the antiinflammatory mechanisms of S.megalantha are likely linked to the decrease in IL- 6 and TNF- $\alpha$ pro-inflammatory cytokines, the effect of the extract on other inflammatory mediators is also essential.

\section{CONCLUSION}

Based on the findings of the present study, the ethanol extract of $S$. megalantha possesses analgesic and anti-inflammatory potentials. However, further studies are necessary to determine precisely the underlying mechanisms of these actions as well as to isolate the active compound(s) responsible for the activities.

\section{ACKNOWLEDGEMENT}

This study was supported by Cellular and Molecular Research Center of Qazvin University of Medical Sciences, Qazvin, Iran and Institute of Medicinal Plants (IMP) of Karaj, Iran.

\section{REFERENCES}

1. Kimura K, Lau Cs, Louw J, Sollano J, Triadiafalopulos G, Xiao Sd, Brooks P. Non-steroidal anti-inflammatory drug toxicity in the upper gastrointestinal tract. $J$ Gastroenterol Hepatol. 2000; 15(3): G58-68.

2. Berger AC, Whistler JL. How to design an opioid drug that causes reduced tolerance and dependence.Ann Neurol. 2010; 67(5): 559-569.

3. Yerima. M, Magaji MG, Yaro AH, Tanko Y, Mohammed MM. Analgesic and anti-inflammatory activities of the methanolic leaves extract of securinega virosa (euphorbiaceae). Nig Journ Pharm Sci. 2009; 8 (1): 47-53

4. Gatta L, Piscitelli F, Giordano C, Boccella S, Lichtman A, Maione S, Di Marzo V. Discovery of Prostamide F2 $\alpha$ and Its Role in Inflammatory Pain and Dorsal Horn Nociceptive Neuron Hyperexcitability. PLoS ONE, 2012; 7(2): e31111.
5. Calandra T, Roger T. Macrophage migration inhibitory factor: a regulator of innate immunity. Nat Rev Immunol . 2003; 3(10): 791-800.

6. Wu GJ, Chen TL, Ueng YF, Chen RM. Ketamine inhibits tumor necrosis factor-a and interleukin-6 gene expressions in lipopolysaccharide-stimulated macrophages through suppression of toll-like receptor 4-mediated c-Jun $N$ terminal kinase phosphorylation and activator protein-1 activation. Toxicol Appl Pharmacol. 2008 ; 228(1): 105-113.

7. Azadmehr A, Afshari A, Baradaran B, Hajiaghaee $R$, Rezazadeh S, Monsef-Esfahani $H$. Suppression of nitric oxide production in activated murine peritoneal macrophages in vitro and ex vivo by Scrophularia striata ethanolic extract. J Ethnopharmacol. 2009; 124: 166-169.

8. Díaz AM, Abad MJ, Fernández L, Silván AM, De Santos $J$, Bermejo P. Phenylpropanoid glycosides from Scrophularia scorodonia: in vitro anti-inflammatory activity. Life Sci. 2004; 74(20): 2515-2526.

9. Dubuisson D, Dennis SG. The formalin test: a quantitative study of the analgesic effects of morphine, meperidine, and brain stem stimulation in rats and cats. Pain 1977; 4(2): 161-174

10. Attar $F$, Joharchi $M R$, Nowrouzi $M$, Hatami $A$. New species of Scrophularia $L$ (Scrophulariaceae) from Iran. Iran J Bot. 2006; 12 (2): 193-202.

11. García $D$, Fernández $A$, Sáenz $T$, Ahumada $C$. Antiinflammatory effects of different extracts and harpagoside isolated from Scrophularia frutescens L. Farmaco. 1996; 51(6): 443-446.

12. Korkina L, Kostyuk V, De Luca C, Pastore S. Plant phenylpropanoids as emerging anti-inflammatory agents. Mini Rev Med Chem. 2011; 11(10): 823835.

13. Costa G, Francisco V, Lopes MC, Cruz MT, Batista MT. Intracellular signaling pathways modulated by phenolic compounds: application for new antiinflammatory drugs discovery. Curr Med Chem. 2012; 19(18): 2876-2900.

14. Abbott FV, Franklin KB, Westbrook RF: The formalin test: scoring properties of the first and second phases of the pain response in rats. Pain .1995; 60(1): 91-102.

15. Walker JS. Anti-inflammatory effects of opioid. Adv Exp Med Biol. 2003; 521: 148-160.

16. Hirano T, Akira S, Taga T, Kishimoto T. Biological and clinical aspects of interleukin 6. Immunol Today. 1990; 11(12): 443-449.

17. Van Damme J, Opdenakker G, Simpson RJ, Rubira MR, Cayphas S, Vink A, Billiau A, Van Snick $J$. Identification of the human $26 \mathrm{kd}$ protein, interferon $f 32$ (IFN fl2), as a $B$ cell hybridoma/plasmacytoma growth factor induced by interleukin 1 and tumor necrosis factor. J Exp Med .1987; 165: 914-919.

18. Salvemini D, Wang ZQ, Wyatt PS, Bourdon DM, Marino $M H$, Manning PT, Currie MG. Nitric oxide: a key mediator in the early and late phase of carrageenan-induced rat paw inflammation. $\mathrm{Br} J$ Pharmacol. 1996; 118(4): 829-838.

19. Loram LC, Fuller A, Fick LG, Cartmell T, Poole S, Mitchell $D$. Cytokine profiles during carrageenan-induced inflammatory hyperalgesia in rat muscle and hind paw. J Pain 2007; 8(2): 127-136. 